\title{
Seed Systems Support in Kenya: Consideration for an Integrated Seed Sector Development Approach
}

\author{
Peter Munyi ${ }^{1}$ \& Bram De Jonge ${ }^{1,2}$ \\ ${ }^{1}$ Law and Governance Group, Wageningen University, Wageningen, The Netherlands \\ ${ }^{2}$ Intellectual Property Unit, Faculty of Law, University of Cape Town, Cape Town, South Africa \\ Correspondence: Peter Munyi, Law and Governance Group, Wageningen University, Hollandseweg 16706 KN \\ Wageningen, The Netherlands. Tel: 31-3-1748-4159. E-mail: peter.munyi@wur.nl
}

Received: January 27, 2015 Accepted: February 9, 2015 Online Published: March 30, 2015

doi:10.5539/jsd.v8n2p161 URL: http://dx.doi.org/10.5539/jsd.v8n2p161

\begin{abstract}
The threats of climate change and rising food prices have stirred renewed attention for seed and food security in Africa, inviting new thinking on the role of seed sector development in coping with these concerns. One conceptual framework that has gained attention is the Integrated Seed Sector Development (ISSD) approach. The ISSD approach has evolved as a response to the almost exclusive focus on formal seed systems in seed sector development programs. Instead, ISSD aims to recognize and support all the diverse seed systems that exist in a particular country. An analysis of the evolution of seed policies and regulatory frameworks in Kenya since independence indeed exposes a continuous support for the formal seed sector while support given to the informal sector has merely been intended to transform it into formal. In reality, however, the formal and informal sectors appear to be made up of a plurality of seed systems, with the informal seed systems being the main source of seed for most crops. The article continues with analysing some of Kenya's recent policy shifts in order to explore how its new seed policy and legislative framework may fit within ISSD principles, and concludes with some recommendations on how the variety of seeds systems that exists on the ground and in particular local seed systems can be supported.
\end{abstract}

Keywords: agriculture, crops, Kenya, seed sector, sustainable development, policy

\section{Introduction}

In most of Africa, agriculture is the main activity providing incomes and livelihoods (World Bank, 2008). Yet, the continent remains one of the most food insecure regions of the world. Kenya is a good example. While agriculture contributes $24 \%$ directly to its GDP and $80 \%$ of its rural population relies on agriculture as their primary source of livelihood (Government of Kenya (GOK, 2010)) at the same time 30\% of the country's total population suffers from chronic food and nutrition insecurity (FAO, 2012). Seed sector development plays a crucial role in fighting food insecurity, both at global, national and local levels. Because the quality of seed determines the success of crops in terms of yield and product quality (Louwaars, 2007), seed quality and availability are crucial elements in securing food security.

A country's seed sector is made up of different seed systems. A seed system may include any individual or institution undertaking breeding research, selection, development, production, multiplication, processing, storage, diffusion, distribution and marketing of seeds. All these components are interrelated (Thiele, 1997). In simplistic terms: a seed system incorporates the different ways by which farmers can access seed, including the different actors involved in the seed chains (Muthoni \& Nyamongo, 2008). Farmers, particularly smallholder farmers, are involved in multiple seed systems, which help them obtain the seed they need. These multiple systems are often broadly divided into two types: the formal (Kloppenburg, 1988) and informal (Cromwell, 1996). When the various components of the seed chain (e.g. breeding, seed production, distribution) are organized and undertaken by public or commercial actors, one normally refers to the formal system. Its opposite, the informal system, is usually defined as the total of farmers' seed production, selection and seed exchange activities (Almekinders \& Louwaars, 1999).

Global food security concerns in the light of climate change and rising food prices have in recent years led to an increased interest in seed sector development in Africa, inviting new thinking on the role of seed in defraying these 
concerns. One conceptual framework that is rapidly gaining attention is the Integrated Seed Sector Development (ISSD) approach. This approach is based on work by Louwaars \& van Marrewijk (1996), and has more recently been elaborated upon in Louwaars \& De Boef (2012) and Louwaars, De Boef \& Edeme (2013). In comparison to more traditional approaches to seed sector development, the ISSD approach can be characterized by three distinctive features: 1) The ISSD approach has evolved as a response to the predominant and exclusive focus on formal seed systems in seed sector development programs, which operate with a linear perspective expecting that informal seed systems will gradually evolve into formal and commercial systems. 2) The ISSD approach instead, emphasizes the plurality of seed systems that exist in a particular country or region, recognizing that farmers typically gain access to seed from different seed systems. 3) In order to strengthen the seed sector in a given country, ISSD aims to support all the different seed systems since all have their own benefits and limitations and require a unique approach in strengthening. As such, the ISSD approach aims to foster pluralism and guide seed policies and programs in their design to strengthen multiple seed systems (Louwaars, De Boef \& Edeme, 2013).

Under the auspices of the African Union's led Africa Seed and Biotechnology Programme (ABSP), ISSD has emerged as an approach for creating coherence among seed practices, programs and policies in Africa. So far, ISSD programs are running in at least nine countries (Note 1) as a basis to improve the effectiveness of a plurality of both formal and informal seed systems, through parallel interventions that may target different crop seeds and different farming systems (Africa Union, 2011). Next to the ISSD country programs, a continental 'ISSD Africa' program was launched in Nairobi in September 2014. This program aims to address complex challenges that hamper seed sector development at local or national levels, but by their specific nature need to be tackled at the continental level (ISSD, 2014).

So far, no ISSD country program has been launched in Kenya. This does not mean that seed sector development is not on the (political) agenda in the country, on the contrary. In the last 10 years, Kenya has progressively made some major policy shifts in the agricultural sector and in the process among others, overhauled more than 131 pieces of legislation in the sector. In 2010, the country adopted a new overarching national seed policy. Subsequently, agricultural sector legislation has been reviewed and repealed in relation to among others, crop research systems; plant breeders' rights; and, seed quality systems. All these policy shifts are intended to lead the country towards food sufficiency and security (Poulton \& Kanyinga, 2014). Without any doubt, the changes made in the agricultural sector generally and the national seed policy in particular will have an impact on the functioning of the seed systems in place and affect farmer practices relating to seed.

This article investigates how the current and past policy frameworks that aim to support seed sector development in Kenya relate to this new ISSD approach. For this purpose, we first briefly analyse the seed policies and regulatory frameworks in Kenya that have evolved since prior to Kenya's independence to the present policy and legislative frameworks. Three main periods of development of seed policies and regulatory frameworks are examined. This overview will expose a division of the seed sector in two domains, the formal and informal, with government support being almost exclusively targeted to the formal seed sector while support given to the informal sector has merely been intended to transform it into formal. When taking the ISSD approach into account, a brief analysis indeed shows the existence of multiple seed systems within both the formal and informal domains. Furthermore, it becomes clear that the formal domain constitutes a very small part of the totality of seed systems in Kenya as most farmers obtain their seed from informal sources such as the saving, exchange or local trade of seed.

The ISSD approach aims to foster pluralism and build programs to support this diversity of seed systems. In order to explore some of the implications the ISSD approach would have for Kenya's current policy framework on seed sector development, two important components of that framework that is, seed quality management and plant variety protection will be discussed in more detail. These two areas have been identified by Louwaars, De Boef \& Edeme (2013) as being amongst the most critical in ISSD guided policy development. The article concludes with some recommendations on what changes could be made to the existing policy and statutory framework in Kenya in order to support the diversity of seeds systems that exists on the ground, in particular seed systems in the informal domain, which provide seed to the vast majority of Kenyan farmers.

\section{Historical Overview}

This section analyses three main periods of development of seed policies and regulatory frameworks in Kenya since prior to Kenya's independence until the present. The first period is the pre-independence era. Kenya's independence in 1963 marked the end of this era as well as the beginning of the second era. The second era commences in 1964 (up to 2004) and was marked by gradual adoption of policies and frameworks in the agricultural sector centralized around a post-independence agenda that sought to have resources directed towards 
activities where productivity would be highest. The third period (from 2004 to present) was precipitated by a new government's quest to revitalize the agricultural sector.

\subsection{Pre-independence Period (up to 1963)}

Pre-independence agriculture in Kenya was characterised by traditional tribal farming, which had developed to cater for subsistence needs. However, the declaration of the East Africa Protectorate by the British Government in 1895 and the subsequent construction of the East Africa Railways had an immediate effect on Kenya's agriculture (Pereira, 1996). The railway was an incentive to invite settlers with capital to develop commercial export agriculture, and importation of farm inputs (seeds and machinery) and exportation of agricultural produce was now possible.

In the lead to independence in 1963, the dominant policy in the agricultural sector that has influenced and shaped seed systems in Kenya is the Swynnerton Plan (Colony of Kenya, 1954). This Plan laid the basis for organizing African smallholder farmers to have them produce high value export cereal and cash crops through provision of improved planting material. It also set in motion policies that sought intensification of African agricultural development through land consolidation, assurance of land title and tenure. However, the importance of food crops such as wheat, rice, maize and pulses was not overlooked. To facilitate the development and marketing of these crops, the government increased financial and technical support to crop-specific research institutions. Co-operative societies were reinvigorated and transformed and their members educated in co-operative principles and business methods with a view to turn these societies to conduits for providing farm inputs and to organise markets for produce.

Implementation of the Swynnerton Plan led to there being at the dawn of Kenya's independence in 1963, a vibrant commercial agriculture sector well supported by policies, institutions and structures. However, this commercial system of agriculture did not replace subsistence agriculture and traditional methods. Communal grazing, shifting cultivation, fragmentation of land holdings and lack of individual land tenure throughout the country still characterised subsistence agriculture (Pereira, 1996). Acquisition and distribution of farm inputs such as fertilizer and seeds, as well as marketing of farm produce was mainly driven through the Kenya Farmers Association, which served the interests of the colonial commercial farmers (Matanga \& Oehmke, 1996). Contrary to the expectations regarding implementation of the Swynnerton Plan, by independence co-operative societies were not strong enough to serve as farm input conduits as earlier anticipated. The informal acquisition, saving and exchange of farm inputs such as seeds remained therefore a vibrant practice amongst farmers.

\subsection{Post-independence I: (1964-2004)}

The main policy framework behind Kenya's post-independence development strategy was the 1965 Sessional Paper No. 10 on African Socialism and its Implications to Planning in Kenya (GOK, 1965). This policy emphasized the following principles: political equality, social justice, and human dignity based on state control of the economy, and it defined the state as the entity that not only should maintain law and order but also outline and implement social and economic programs in a bid to remedy historical and social inequities (Nyangito \& Okello, 1998).

The government, as an example of African socialism at work earmarked the seed sector. As the Sessional Paper No. 10 stated, 'almost every form of organization will be utilized in this sector including national farms, co-operatives, companies, partnerships and individual farms.' State farms were targeted as the main producer of hybrid seed. The principles contained in Sessional Paper No.10 gave credence to the state's control of the seed chain for the important food crops from plant breeding to multiplication and distribution. Legislation was thereafter crafted to fit with these principles. Thus, through the 1972 Seeds and Plant Varieties Act (1972 SPVA), the state was given the power to regulate seed testing and certification; imposition of regulation on introduction and importation of seeds and new varieties; and, to grant plant breeders' rights. Implementation of various aspects of the 1972 SPVA was progressive starting with seed testing and certification. It was not until 1995 that regulations to give better effect to the plant breeders' rights provisions in the 1972 SPVA were put in place, leading to the first grant of such right being made in 1999.

A number of exogenous factors also led to the shaping of the seed sector policies and programs from the 1970s to the 1990s. For example, food shortages experienced in the late 1970s and early 1980s led to the adoption of the Sessional Paper No. 4 of 1981 on National Food Policy (GOK, 1981), which increased emphasis on breeding programmes, aimed at providing farmers with improved varieties. In Sessional Paper No. 1 of 1986 on Economic Management for Renewed Growth (GOK, 1986), which implemented the World Bank's structural adjustment programmes some food crops (maize, beans, wheat and sorghum) were identified as key for which policy was proposed to increase productivity and self-sufficiency. Finally, the decline of the global market for export 
crops-tea and coffee in the late 1990s led to the adoption of Sessional Paper No. 2 of 1999 (GOK, 1999) on the Liberalization and Restructuring of the Tea Industry and Sessional Paper No. 2 of 2001 on Liberalization and Restructuring of the Coffee Industry (GOK, 2001). These two policies sought to separate breeding research and marketing functions with respect to tea and coffee, on the assumption that such separation would yield market efficiencies.

Sessional Paper No. 10 of 1965 as well other post-independence policies responding to exogenous issues all similarly intensified support for the formal sector and in particular a few select food crops- mainly cereals, and cash crops. However, informal seed sources continued to provide the bulk of seed for most food crops particularly legumes and vegetatively propagated crops such as cassava, banana and sweet potato.

\subsection{Post-independence II: (2004- present)}

In 2004, the government adopted the Strategy for Revitalization of Agriculture (SRA) "with a view to transform agriculture into a more competitive and commercial sector" (GOK, 2004). This policy was largely driven by a new government that came to power in 2002, which held the view that the agricultural sector required revival. The strategy also sought to limit the government's role in the sector to only providing a limited range of public goods and services, and to regulate in those aspects where private self-regulation was not possible or codes of conduct appeared insufficient. Furthermore, the strategy sought to improve delivery of research and to increase access to farm inputs (Odame \& Muange, 2010), and also reinvigorated financing of agricultural research through donor funding.

The SRA was the basis for the development of the 2010 National Seed Policy (GOK, 2010). It also laid the foundation for the overhauling of over 131 pieces of legislation in the agricultural sector and the amendment of the 1972 SPVA through the 2012 Seeds and Plant Varieties (Amendment) Act (the 2012 SPVA Amendment); the enactment of the 2013 Crops Act; and, the 2013 Kenya Agricultural and Livestock Research Act. The National Seed Policy and these three legislations are now the designated policy instruments to steer agricultural development activities in Kenya. Invariably, all these four instruments affect seed sector issues, directly or indirectly. These four policy instruments are briefly described below.

\subsubsection{National Seed Policy}

The National Seed Policy outlines interventions that aim to address constraints in the seed sector with a view to contribute to agricultural productivity. From the outset, the description of seed systems in the policy follows the formal/informal dichotomy. The formal component is served by government initiated research programmes for some benefactor food and cash crops. Lumped within the informal seed system component are farm-saved seed, seeds purchased, multiplied or marketed locally between farmers and, seed accessed through civil society organizations, or imported by unregistered seed dealers, and relief agencies. The description of the informal seed system in the National Seed Policy is not followed by any policy detail on whether the system either requires attention or support or to be abolished.

Use of farm-saved seed, and seed obtained either through farmer-to-farmer exchange and local markets is identified as a problem. Whereas the specific problem presented by these seeds is not pointed out in the policy itself, it is apparent from the SRA that the quality of these seeds is the perceived problem. Seed certification is presented as the main tool effecting quality control. To enhance certification the policy proposes registration of all actors in the seed value chain (including relief seed suppliers) and prescription of stiffer penalties for those flouting certification procedures. There is also a call for the continued support of public breeding institutions to maintain varieties and produce seed for those varieties not attractive to the private sector. Targeting informal seed systems is a proposed policy on 'provision of advisory services with a view to transform it to the formal sector' (National Seed Policy, 2010). While the nature of advisory services are not expounded, the policy calls for strengthening of farmer extension and advisory services with a view to make farmers appreciate the benefits of using good quality seed. It is expected that through these services this transformation to formal will occur.

\subsubsection{SPVA Amendment}

The principal objective of the 2012 SPVA Amendment was to amend the 1972 SPVA, albeit not in its entirety. As such, the 1972 SPVA is still operative although in the form amended by the 2012 SPVA Amendment. One key amendment is to upgrade the plant breeders' rights system in Kenya from it being based on the 1978 Act of the International Convention for the Protection of New Varieties of Plants (UPOV) to being framed under the stricter 1991 Act of UPOV (UPOV 1991). Plant breeders' rights, their limitations and exceptions are now largely based on UPOV 1991 principles with the expectation that this will stimulate breeding as well as the introduction of foreign varieties into the country, and that ultimately this will bring more varieties to the market. Under UPOV 
1991, farmers are only allowed to save and re-use seed of a protected variety "on their own holding" and "within reasonable limits and subject to safeguarding the legitimate interests of the breeder" which may imply that farmers have to pay a royalty to remunerate the breeder. The exchange and sale of farm-saved seed, as is common practice amongst farmers in informal seed systems, is now prohibited for protected varieties (De Jonge, 2014).

\subsubsection{Crops Act}

The primary novelty of the 2013 Crops Act regarding seeds is the classification of crops as either scheduled or non-scheduled. 112 crops varying from food, cash, and vegetable crops to fruit trees are listed as scheduled crops with the Minister for agriculture having power to increase the number of these crops. The difference between scheduled and non-scheduled crops lies in the requirement for government authorities to assist the development and market promotion of each scheduled crop. As laid out in section 8 of this statute, these measures include establishing experimental stations and seed farms for suitable varieties, facilitating marketing and distribution of the produce of these crops, and devising strategies for value addition for export crops.

Virtually, all food crops grown in Kenya are listed as scheduled crops. While the rationale for this classification is not clear, it is likely to induce the market structures that will be prevalent for these crops and influence farmer options and choices, as it obliges the government to not only set seed quality standards but also to determine the cost of farm inputs, and provision of markets for produce. This statute also requires active participation by government in the crop value chain for virtually all crops, and shows the intention of the government to formalise the entire seed sector.

\subsubsection{Kenya Agricultural and Livestock Research Act}

The 2013 Kenya Agricultural and Livestock Research Act seeks to overhaul the structure of the agricultural research system in Kenya, by merging various agricultural research institutions in the food crop, cash crop and livestock sectors (Note 2). From the outset, section 5 of this statute emphasizes that the principal function of the restructured organization is regulation, promotion, streamlining and coordinating agricultural research. Unlike in the past scenario where some of the agricultural research institutes such as KARI are carrying out plant breeding as well as seed multiplication and distribution, the intended focus of these public institutions under the new structure appears limited to undertaking research only. Any actions of the organization in dissemination of research outcomes appear limited to training and building capacity of users, and activities for demonstration purposes. This may have implications for smallholder farmers, as it removes KARI from participating in downstream seed activities (as KARI currently does), which is important in terms of ensuring that there is downstream support for improved varieties for crops that may not be attractive to the private sector.

Table 1. Overview of main agricultural sector policy drivers in Kenya

\begin{tabular}{lll}
\hline Era & Main Policy drivers \\
\hline Pre-independence & - & 1895 Declaration of East Africa Protectorate \\
(up to 1963) & - & 1954 Swynnerton Plan \\
Post-independence I: & - & 1965 Sessional Paper No. 10 on African Socialism and its Implications to \\
$1964-2004$ & & Planning \\
& - 1981 Sessional Paper No. 4 on National Food Policy \\
& - 1986 Sessional Paper No. 1 on Economic Management for Renewed Growth \\
& - 1999 Sessional Paper No. 2 on the Liberalization and Restructuring of the Tea \\
& - Industry \\
& - 2001 Sessional Paper No. 2 on Liberalization and Restructuring of the Coffee \\
& Industry \\
Post-independence II: & - 2004 Strategy for Revitalization of Agriculture \\
$2004-p r e s e n t$ & &
\end{tabular}

From the above, it is apparent that policy programmes and reforms adopted in the agricultural sector before and after independence (Table 1) have had the effect of rendering support for the formal seed sector while support 
given to the informal sector has merely been intended to transform it into formal. This policy fixation on the formal sector at the expense of recognition for the diversity of seed systems on the ground has been a raison d'être for the ISSD approach. As explained above, the ISSD approach has evolved as a response to the exclusive focus on formal seed systems in seed sector development programs as this traditional policy approach neglects the value of non-formal seed systems while it appears to be ignorant of the limitations of the formal sector. While it is questionable whether intensification of support for formal seed systems will lead to alleviation of food security problems (Louwaars \& De Boef, 2012), it also emerges that there is very little understanding of the various seed systems in place in Kenya. In order to strengthen seed sector development, a comprehensive understanding of the various seed systems that exist on the ground is needed (Sperling, Osborn \& Cooper, 2004). Sperling, Osborn and Cooper (2004) also observe that farmers, particularly smallholder farmers, are involved in multiple kinds of sometimes overlapping seed systems which help them produce and obtain the seed they need. This is true for Kenya as will be shown in the next section.

\section{A Plurality of Seed Systems in Kenya}

In this section, a general overview is provided of the diversity of seed systems that exist within both the informal and formal domains. This general overview shows the main categories in which the various seed systems in Kenya can be divided.

\subsection{Informal Seed Systems}

The informal seed sector in Kenya can be divided in at least three different categories: farmer-based seed systems, community-based seeds system, and relief seed systems. These categories are not absolutely distinct but sometimes overlap depending on the types of crops and seed value chains operating.

Farmer-based seed systems are characterised by individual farmers saving seed from harvests, exchanging seed with their neighbours or purchasing grain from the local market and using the same as seed (Almekinders \& Louwaars, 1999). In many cases, it also involves individual farmers selling excess farm produce to other farmers as seed. The bulk of seed and planting material for vegetatively propagated crops- sweet potato $(96 \%)$, cassava (93\%) and bananas (80\%) is mostly obtained from farm-saved sources (Ayieko \& Tschirley, 2006). For legumes and small-grain cereals Ayieko \& Tschirley (2006) have found the scenario as similar, as $80 \%$ of bean seed, $75 \%$ of cowpea seed, $90 \%$ of millet seed and $87 \%$ sorghum seed is obtained from farm-saved sources. Hybrid maize is the least, with only $15 \%$ of seed being farm-saved (Ayieko \& Tschirley, 2006). Ayieko and Tschirley (2006) estimate that for all crops cultivated in Kenya, $78 \%$ of seed used comes from informal seed sources. Smallholder farmers, whose farm size averages $0.2-3$ hectares, account for $75 \%$ of the total agricultural output and $70 \%$ of marketed agricultural produce (GOK, 2010). As such, seed from farmer-based seed systems contributes substantially towards the total agricultural output in Kenya.

Community-based seed systems involve associations of individuals, often organized as a group or cooperative through the support of non-governmental organizations or state agents that assist them in entrepreneurial forms of seed multiplication and the marketing of seeds. These systems are established either to support other farming systems recovering from systemic stress such as drought, pests or diseases or to strengthen farmer-based systems with improved varieties or seed quality enhancing techniques. Unregulated (informal) seed quality control mechanisms are usually found in these systems. One of the results of the Great Lakes Cassava Initiative (GLCI), a collaborative project between Catholic Relief Services (CRS) and national agricultural research institutes in Kenya and other countries is the establishment of a community-based seed system for cassava in western Kenya. Through this system, some farmers have been organized and trained by KARI to produce and distribute Cassava Brown Streak Disease (CBSD) and Cassava Mosaic Disease (CMD)-free cassava planting material to other small-holder farmers.

Relief seed composes another critical seed system. Like other countries in the Horn of Africa, Kenya experiences drought from time to time (Sperling, Remington, Haugen \& Nagoda, 2004). Seed aid programmes to assist the afflicted famers overcome acute stress emerged as early as the 1990s. Seed aid programmes have been carried out by the government in certain areas as a result of drought or internal displacement of farming populations. Non-governmental organizations such as CRS have also been engaged in seed aid activities since 1992, distributing both certified and farmer-produced seed. Official and unofficial maize seed aid, followed by vegetable seed aid (tomatoes, kale and onions) has dominated in relief seed recipient areas. Sperling et al (2004) have found that seed aid has been delivered on a fairly large scale about every other season, and across a large number of districts in Kenya. 


\subsection{Formal Seed Systems}

The formal seed sector in Kenya is also composed of multiple seed systems. Here, three main categories that can be discerned are the public formal seed systems, mixed public private seed systems, and closed value chains.

Public formal seed systems refer to seed systems wherein the public sector undertakes all the activities in the seed value chain - from breeding to seed distribution. The wheat seed system in Kenya is one example of a public formal seed system. While it is not the only mode of delivery of seed to farmers for this crop, public formal sources are the second most important source of seed for wheat after farmer-based seed sources (Mahagayu, Ndiema, Njeru, Macharia \& Rengine, 2010). Currently, all wheat-breeding activities are undertaken by KARI, which also undertakes seed production, multiplication and distribution through its own KARI Seed Unit and contracted seed growers. Furthermore, it also contracts the Agricultural Development Corporation (ADC), a state agent for seed multiplication. Besides wheat seed distribution being undertaken through ADC and its own KARI Seed Unit, wheat seed distribution is also undertaken through the National Cereals and Produce Board, another government agent.

Mixed public private seed systems are characterized by participation of both the public and private sector in the seed value chain. The public sector usually undertakes breeding research while the private sector multiplies and distributes seed to farmers. Private sector participation in seed value chains in Kenya is vibrant albeit to varying degrees. There are around 100 registered seed companies in Kenya. Most of these companies undertake seed multiplication and distribution, leaving plant-breeding research, which is capital intensive and risky to KARI. Thus, most seed companies obtain breeder material, mainly maize but also beans and other legumes, from KARI and these are multiplied under supervision by the Kenya Plant Health Inspectorate Service (KEPHIS) (Note 3).

Closed value chain seed systems refer to those seed systems that are entirely controlled by the private sector from plant breeding through to distribution of seed to farmers and the marketing (and processing) of their produce. They are characterized by minimal government involvement in the value chain except in seed quality control and certification, mainly to prevent introduction of pests and diseases. In Kenya, fruit crops, vegetable crops, flowers and tobacco dominate this system. These value chains are dominant in utilizing plant breeders' rights. For example, in the 2010/2011 financial year, of the 69 applications for plant breeders' rights made in Kenya 30 were in respect of roses (KEPHIS, 2011).

Table 2. Plurality of seed systems in Kenya

\begin{tabular}{|c|c|c|}
\hline Seed & on & $\begin{array}{l}\text { Examples of crops in the } \\
\text { system }\end{array}$ \\
\hline $\mathrm{Fa}$ & $\begin{array}{l}\text { Seed saved, used, exchanged and sold between individual } \\
\text { farmers. }\end{array}$ & $\begin{array}{l}\text { Sweet potato; Irish potato; } \\
\text { bananas; beans; cowpea; } \\
\text { millet; sorghum }\end{array}$ \\
\hline $\begin{array}{l}\text { Community- } \\
\text { based }\end{array}$ & $\begin{array}{l}\text { Seeds produced, multiplied and either sold or shared within a } \\
\text { community }\end{array}$ & \\
\hline Relief seed & $\begin{array}{l}\text { Civil society organisations, non-governmental organisations } \\
\text { and relief agencies purchase seed either from the public and } \\
\text { private sector and distribute to farmers }\end{array}$ & $\begin{array}{l}\text { Hybrid maize; OPV maize; } \\
\text { tomatoes; kale; onions }\end{array}$ \\
\hline Public formal & $\begin{array}{l}\text { Breeding, seed production, multiplication and distribution by } \\
\text { public sector only }\end{array}$ & Wheat; hybrid maize \\
\hline $\begin{array}{l}\text { Mixed } \\
\text { public/private }\end{array}$ & $\begin{array}{l}\text { Breeding undertaken by public sector; seed production, } \\
\text { multiplication and distribution by private sector }\end{array}$ & $\begin{array}{l}\text { Hybrid maize; OPV maize; } \\
\text { beans }\end{array}$ \\
\hline $\begin{array}{l}\text { Closed value } \\
\text { chains }\end{array}$ & $\begin{array}{l}\text { Breeding, seed production, seed multiplication and seed } \\
\text { distribution all undertaken by private sector only. }\end{array}$ & Pineapples; flowers; tobacco \\
\hline
\end{tabular}

Source: adapted from Sperling, Remington, Haugen \& Nagoda (2004); Ayieko \& Tschirley (2006); Mahagayu, Ndiema, Njeru, Macharia \& Rengine (2010) 
From the above one can discern a wide range of seed systems operating in Kenya (Table 2). This is in contrast with the National Seed Policy, which frames seed systems to narrowly fit into formal and informal dichotomies without exploring the diversity or plurality of seed systems within each domain. In addition, a perception has existed and continues to exist that only formal seed systems may be able to deliver better quality seeds to farmers. However, these seed systems have not delivered the perceived outcomes over the years and there is no evidence that they will do so in future. Even more importantly, this notion neglects the importance and benefits of informal seed systems, which may be quicker to respond to external stresses and farmers' needs (Louwaars \& De Boef, 2012). The next section will explore some potential changes that could be made to the existing policy framework on seed sector development in Kenya in order to support the diversity of seeds systems that exists on the ground and in particular, those seed systems in the informal domain, which provide seed to the vast majority of Kenyan farmers.

\section{Consideration for an ISSD-Approach}

The goal of the ISSD approach is to enhance farmers' access to quality seed of superior varieties, with superior varieties referring to both improved and local varieties most preferred by farmers (ISSD, 2014). Two important policy components that can strongly influence smallholder farmers access to quality seed of superior varieties are seed quality management and plant variety protection (Louwaars, De Boef \& Edeme, 2013). This section will discuss some of the implications the ISSD approach would have for Kenya's current policy framework in these two policy fields.

\subsection{Seed Quality Management}

Seed certification and quality control guarantee varietal identity and purity as well as physiological, physical and sanitary quality. However, compulsory certification has its limitations (Tripp \& Van der Burg, 1997). Investments and running costs for seed certification and testing schemes are usually high. Even where seed producers cover the costs of these schemes, capacity in the seed quality and testing organizations is often limited.

Kenya's approach to seed certification and seed quality is by strengthening seed certification rules through the 2010 National Seed Policy (section 2.3.1). The policy proposes registration of all actors in the seed value chain (regardless of their nature, and the seed systems they operate in) and aims to ensure that specific crops are certified with severe legal punishment being visited upon those found flouting the regulations. Of the 37 crops (Table 3) for which certification is either mandatory or voluntary as enumerated under the Crops Act, 2013, 21 are food crops. Under the new legislation, any person who contravenes any provision of the 2012 SPVA Amendment and is found guilty may be liable to a fine not exceeding Kenya Shillings two million (approximately USD 22,000) or may be imprisoned for a term up to two years. Previously, anyone found guilty for having committed similar offences under the 1972 SPVA was only liable to a fine not exceeding KSh. 3,000 (approximately USD 35) or imprisonment for a period not exceeding three months. Under the 2012 SPVA Amendment, the rules relating to dealing with uncertified seed are broad enough to include control over smallholder farmers' practices, particularly those engaging in seed trading at local markets.

The policy also aims to ensure that the private sector may participate in seed certification and testing procedures. Obviously, the private sector will only get involved in such practices where it will have a positive effect on profits. With respect to food security crops for which certification is mandatory, the private sector is not likely to offer certification services at cost or subsidized rates as is the government. Unless there is an increased competition in the private sector certification services, private certification is not likely to lead to a decrease, but rather to an increase of costs for seed testing and certification of these crops. These increased costs will in turn be passed on to the farmer with the resultant effect being an increase of the cost of access of seed.

In an ISSD framework, seed certification and testing may not be necessary for some seed systems, e.g. closed value chain systems where the seed producer has a direct interest in delivering the right type of seed, and it may not be feasible for others, e.g. farmer-based seed systems where farmers save and exchange seed amongst themselves. The burden of full certification can be lessened through the adoption of a 'quality declared seed' (QDS) system. This is useful particularly where seed is produced by farmers or farmer groups for the local markets and in small quantities. QDS is a quality assurance scheme for seed production, which is less demanding than full quality control systems and, thus, can be more easily implemented in situations where resources are limited (FAO, 2010). The scheme involves seed sampling in fields and/or the inspection of whole seed lots. QDS procedures also involve lesser numbers of field inspections, thus decreasing seed quality management costs, and ultimately reducing the price of seed for the farmer while ensuring a certain standard of seed quality.

According to Granqvist (2006) a QDS system should not be perceived as a competitor to existing seed trade, nor designed to replace a fully developed seed certification program. In itself, a QDS system may facilitate the 
growth and sustainable development of the seed trade by creating local entrepreneurs, leading to a robust seed sector (De Boef, Dempewolf, Byakweli \& Engels, 2010). The parameters within which a QDS system should operate may be outlined in national legislation. In Tanzania, for example, a QDS system has been incorporated in the 2003 Seeds Act, and guidelines for control of QDS production were introduced in 2007 specifying the production process, the criteria that the farmer producer must meet, and the crops whose seeds may be produced in this manner-

Applying the ISSD approach to seed certification to the current policy framework in Kenya, one finds that the list of crops for which certification is mandatory does not take into account the seed systems these crops operate in. For example, most of seed for Irish potato and beans for which mandatory certification is now a requirement is accessed through informal sources. Whereas a case could be made for the need to have improved varieties of these crops being available, it is questionable whether the formal sector alone will be able to satisfy the demand for quality seed anywhere soon, and the current policy framework does not provide space for alternative mechanisms through which the production of quality seed could be enhanced. A QDS framework, for example, could support the production and multiplication of quality seed of Irish potato and beans by small businesses at the local level. To create space for such farmer or community-based seed businesses, the current legislation will have to be amended by introducing the QDS system and specifying the crops for which this type of certification will be allowed, which should include food security crops, such as hybrid and OPV maize, wheat, sweet potatoes and millets. For crops such as sunflower, which operate in closed value chains, emphasizing on use of certified seed may not be necessary since the value chain structure itself is able to regulate this issue.

Table 3. Food crops for which seed certification is either mandatory of voluntary

\begin{tabular}{ll}
\hline Food crops for which certification is mandatory & Food crops for which certification is voluntary \\
\hline (1) Irish potatoes (2) Sunflower (3) Soya beans (4) Beans & (1) Bananas (2) French beans (3) Cassava (4) Sweet \\
(5) Barley (6) Finger millet (7) Maize hybrid and OPV & potato (5) Sesame (6) Ground nut (7) Pigeon pea (8) \\
(8) Pearl millet (9) Rice (10) Sorghum (11) Wheat & Dolichos bean (9) Cow pea (10) Chick peas \\
\hline
\end{tabular}

Source: adapted from Schedule to the Crops Act, 2013.

\subsection{Plant Breeders' Rights}

Plant breeders' rights (PBRs) aim to encourage plant breeding by granting breeders of new plant varieties an exclusive right on the commercialisation of their varieties. Many breeders and breeding companies consider an effective PBR system a prerequisite for developing and marketing new varieties in a particular country. The 2012 SPVA Amendment seeks to steer Kenya towards compliance with UPOV 1991, which currently provides the strongest, internationally recognized PBR system. The potential benefits of such a system are that it may incentivize public and private breeding and facilitate the introduction of foreign-bred varieties. This would ultimately provide farmers access to a wider range of improved varieties. However, the UPOV system is exclusively aimed at supporting formal seed systems and ignores others. Furthermore, UPOV 1991 is likely to affect the informal sector as it does not allow for the exchange of farm-saved seed of protected varieties through the sales of seed surpluses on the local market (De Jonge, 2014).

It is not in doubt that compliance with UPOV 1991 will be beneficial to some of Kenya's sectors such as horticulture, which utilize this system the most. However, this might not be the case for other crops, food crops especially (with the exception of hybrid maize). A key issue is that a UPOV 1991 framework may not provide a sufficient balance between the exclusive rights of breeders and the rights of farmers to save, exchange and trade protected planting material, which is an essential ingredient in ISSD.

In an ISSD framework, differentiation between rights and limitations for different categories of farmers and crops could be introduced. This will ensure that a blanket implementation of plant breeders' rights does not negatively impact on smallholder farmers, and a pluralistic approach to seed sector development is supported (Louwaars, De Boef \& Edeme, 2013). One way of doing this is by incorporating different levels of protection for different crops and/or with respect to different categories of farmers (De Jonge, 2013). For example, certain categories of farmers and crops - especially those operating in farm-saved seed systems (Table 2), could be allowed to save, sell and exchange seed of protected varieties amongst themselves. A key challenge of such differentiated PBR system is to regulate structures and boundaries between the different levels of farmers and crops. One possible example is provided by the Ethiopian draft PBR Proclamation, which creates three levels of 
rights. For the commercial export crops, such as flowers, breeders get full protection with no rights for farmers to save seed. For food crops, breeders get protection but farmers have the right to reproduce seed on their own holding. Yet, for all crops, smallholder farmers have the right to exchange and sell seed amongst themselves. This draft Proclamation defines a smallholder farmer in terms of income levels, with total earnings from sales of farm-saved seed not exceeding the average household income (De Jonge, 2013).

In theory, UPOV 1991 itself could provide for a differentiated PBR system through its exemption for private and non-commercial use. Since UPOV 1991 does not define private and non-commercial use member countries are free to define the farming practices, which they considered to fall within the scope of this exception (De Jonge, Hickling \& Warner, 2015). Remarkably, Kenya's 2012 SPVA Amendment, which was implemented with the aim to make Kenya's PBR law compliant with UPOV 1991 does not include the private and non-commercial use exemption as required by UPOV. The current SPVA Amendment leaves, as such, little room for smallholder farmers to be allowed to freely use farm-saved seed of protected varieties. To implement an ISSD approach to PBRs in Kenya's current legal framework would require at least two things: first, an amendment of the 2012 SPVA Amendment with a view to include the private and non commercial use exemption. The second would be differentiation in the implementing regulations to the current PBRs framework, of farmers and crops that could be allowed to save, sell and exchange seed of protected varieties amongst themselves.

In sum, infusing an ISSD approach to seed quality management and PBRs in the current policy framework on seeds is likely to have a positive impact on how smallholder farmers access seed. A QDS system will lead to better quality seed for certain crops being available and at a lesser cost. Introducing provisions that recognize certain rights or exemptions for smallholder farmers in the PBR system will achieve a similar result by allowing such farmers to freely use protected varieties. These ISSD elements are not likely to negatively affect the already thriving commercial seed sector. The set of farmers and crops for which this sector caters for does not farm for survival and subsistence purposes. Given the many Kenyan farmers that depend on the informal sector for their seed security, policy support for all the various seed systems that can be found on the ground may well be the only way to achieve food security and economic development in the country.

\section{Conclusions}

This article reveals that from the pre-colonial era until today, the Kenyan government has continuously offered support to the further development of formal seed systems. Any agricultural policy change that has taken place over the years has had the intention of intensifying this support. Any support and recognition given to other seed systems, which have neither been defined nor analysed in detail in any policy frameworks so far, has been intended to transform these systems into formal systems. Yet, formal seed systems are the basis for provision of only a minor fraction of seeds of a limited number of crops to farmers. Notwithstanding policy change access to seed problems have continued to exist, making it necessary for alternative approaches to be considered and elaborated. As an alternative approach, ISSD offers opportunities to develop seed policies for the simultaneous and parallel development of various seeds systems that together cater for the diversity of demands related to different crops, farming systems and farmers (Louwaars, De Boef \& Edeme, 2013).

The seed quality management procedures currently in place in Kenya are designed for formal seed systems only. They do not provide flexibility to accommodate the functioning of other seed systems besides those operating in the formal domain. Alteration of these procedures through introduction of quality declared seed programmes with a view to accommodate the plurality of seed systems in place and to even recognize diversity of use within crops is likely to lead to an increase of the quality of seeds available to farmers and spur local seed businesses, which supports sustainable and robust seed systems.

As currently designed, plant breeders' rights as incorporated under the 2012 SPVA Amendment prohibit farmers from exchanging or selling farm-saved seed of protected varieties. Noting that smallholder farmers access seed predominantly through these channels, this provision locks out many farmers from accessing quality seed and planting material. It is therefore important that more flexibilities be introduced in the plant breeders' rights regulations to allow for certain categories of farmers or for certain crops to save, exchange and sell farm-saved seeds of protected varieties in local markets so that current seed access channels are not stifled.

All the proposed considerations above fall within the ISSD approach and follow from its concept. The current policy and legislative framework in Kenya does not recognize these flexibilities and opportunities. For it to fully recognize the crucial importance of the diversity of seed systems and, in particular, of the informal seed systems on which the vast majority of Kenyan farmers depend for their seed security, such amendments are highly recommended. 


\section{Acknowledgements}

This work is part of the research programme Responsible Innovation, which is financed by the Netherlands Organisation for Scientific Research (NWO). We would like to thank Bert Visser, Niels Louwaars, Abishkar Subedi, Bernard Maister, Marcelin T. Mahop and the anonymous reviewer for their useful comments.

\section{References}

African Union Commission. (2011). Communiqué on Integrated Seed Sector Development. Retrieved from https://www.wageningenur.nl/en/show/Integrated-seed-sector-development-in-Africa.htm

Almekinders, C. J. M., \& Louwaars, N. P. (1999). Farmers' seed production: New approaches and practices. London, Intermediate Technology Publications. http://dx.doi.org/10.3362/9781780442150

Ayieko, M. W., \& Tschirley, D. L. (2006). Enhancing Access and Utilization of Quality Seed for improved food security in Kenya. Tegemeo Institute of Agricultural Policy and Development. Working Paper No 27/2006.

Colony of Kenya. (1954). Swynnerton Plan. Nairobi: Colony of Kenya.

Cromwell, E. (1996). Governments, farmers and seeds in a changing Africa. Wallingford, UK, CABI Publishing.

de Boef, W. S., Dempewolf, H., Byakweli, J. M., \& Marie Engels, J. M. (2010). Integrating Genetic Resource Conservation and Sustainable Development into Strategies to Increase the Robustness of Seed Systems. Journal of Sustainable Agriculture, 34(5), 504-531. http://dx.doi.org/10.1080/10440046.2010.484689

De Jonge, B. (2013). Possibilities for a differentiated PVP regime. In M.T. Mahop, B. De Jonge, \& P. Munyi (Eds.), Seed systems and intellectual property rights: an inventory from five Sub-Saharan African countries (pp. 44-54). Report for the Ministry of Economic Affairs, Agriculture and Innovation, the Netherlands. Retrieved from http://www.wageningenur.nl/en/Publication-details.htm?publicationId=publication-way-343339363734

De Jonge, B. (2014). Plant Variety Protection in Sub-Saharan Africa: Balancing Commercial and Smallholder Farmers' Interests. Journal of Politics and Law, 7(7). http://dx.doi.org/10.5539/jpl.v7n3p100

De Jonge, B., Hickling, B., \& Warner, N. (2015). Report of High Level Round-Table Meeting on Plant Variety Protection in Africa 27-28 th November 2014. Retrieved from http://www.issdseed.org/resource/high-level-round-table-meeting-plant-variety-protection-africa-27-28th-n ovember-2014

FAO. (2010). Quality declared planting material: protocols and standards for vegetatively propagated crops. Rome, FAO.

FAO. (2012). Kenya Economic Indicators. Retrieved from http://faostat.fao.org

Government of Kenya. (1965). Sessional Paper No. 10 of 1965 on African Socialism and its Implication on Planning in Kenya.

Government of Kenya. (1981). Sessional Paper No. 4 of 1981 on National Food Policy.

Government of Kenya. (1986). Sessional Paper No.1 of 1986 on Economic Management for Renewed Growth.

Government of Kenya. (1999). Sessional Paper No. 2 of 1999 on the Liberalization and Restructuring of the Tea Industry.

Government of Kenya. (2001). Sessional Paper No. 2 of 2001 on Liberalization and Restructuring of the Coffee Industry.

Government of Kenya. (2004). Strategy for Revitalisation of Agriculture.

Government of Kenya. (2010). National Seed Policy.

Granqvist, B. (2006). Is Quality Declared Seed Production an effective way to address Seed and Food Security in Africa? FAO Plant Production and Protection Paper No. 185.

Integrated Seed Sector Development. (2014). Outline of the Piloting Phase for a Comprehensive Program on Integrated Seed Sector Development in Africa: Sept 2014-Aug 2016. Centre for Development Innovation Wageningen UR, August 2014, Wageningen.

Kenya Plant Health Inspectorate Service. (2012). Annual Report and Financial Statements for 2010/2011. 
Kloppenburg, J. R. (1988). First the seed: The political economy of plant biotechnology, 1492-2000. Cambridge, Cambridge University Press.

Louwaars, N. (2007). Seeds of confusion: The impact of policies on seed systems (Unpublished doctoral thesis), Wageningen University, Wageningen, The Netherlands.

Louwaars, N. P., \& de Boef, W. S. (2012). Integrated Seed Sector Development in Africa: A Conceptual Framework for Creating Coherence Between Practices, Programs, and Policies. Journal of Crop Improvement, 26(1), 39-59. http://dx.doi.org/10.1080/15427528.2011.611277

Louwaars, N. P., \& van Marrewijk, G. A. M. (1996). Seed Supply Systems in Developing Countries. Wageningen, CTA.

Louwaars, N. P., de Boef, W. S., \& Edeme, J. (2013). Integrated Seed Sector Development in Africa: A Basis for Seed Policy and Law. Journal of Crop Improvement, 27(2), 186-214. http://dx.doi.org/10.1080/15427528.2012.751472

Mahagayu, M. C., Ndiema, A. C., Njeru, C. M., Macharia, N., \& Rengine, P. (2010). Smallholder Wheat Production and Marketing in Timau Division Meru County. Presentation made at the $12^{\text {th }}$ KARI Biennial Scientific Conference, 8-12 November, 2010.

Matanga, D. W., \& Oehmke, J. F. (1996). The History of and Returns to Kenya Wheat Research. Mimeo. Department of Agricultural Economics, Michigan State University.

Muthoni, J., \& Nyamongo, D. O. (2008). Seed Systems in Kenya and Their Relationship to On-Farm Conservation of Food Crops. Journal of New Seeds, 9(4), 330-342. http://dx.doi.org/10.1080/15228860802492273

Nyangito, H., \& Okello, J. (1998). Kenya's agricultural policy and sectors performance: 1964-1996. Retrieved from

http://www.chr.up.ac.za/chr_old/indigenous/documents/Kenya/Report/Kenya\%27s\%20Agricultural\%20Pol icy\%20and\%20Sector\%20Performance.pdf

Odame, H., \& Muange, E. (2010). Can Agro-dealers deliver the green revolution in Kenya? Future Agriculture. Working Paper No. 014.

Pereira, C. (1996). The Role of agricultural research in development of Kenya before independence. In P. D. Smith, R. A. Tyler, \& E. M. Young (Eds.), Review of Kenyan Agricultural Research. Nairobi: KARI.

Poulton, C., \& Kanyinga, K. (2014). The Politics of Revitalising Agriculture in Kenya. Development Policy Review, 32, s151-s172. http://dx.doi.org/10.1111/dpr.12080

Sperling, L., Osborn, T., \& Cooper, D. (2004). Towards effective and sustainable seed relief activities. Rome: FAO.

Sperling, L., Remington, T., Haugen, J. M., \& Nagoda, S. (Eds.). (2004). Addressing Seed Security in Disaster Response: Linking Relief with Development. Cali, Colombia: International Center for Tropical Agriculture.

The World Bank. (2008). World Development Report: Agriculture for Development. The World Bank, Washington DC: the World Bank.

Thiele, G. (1997). Informal Potato Seed Systems in the Andes: Why Are They Important and What Should We Do with Them? Cochabamba: PROINPA. MS.

Tripp, R., \& Van der Burg, W. J. (1997). The conduct and reform of seed quality control. In R. Tripp (Ed.), New seed and old laws: regulatory reform and the diversification of national seed systems (pp. 121-126). Intermediate Technology, London. http://dx.doi.org/10.3362/9781780445588.006

\section{Notes}

Note 1. Burundi, Ethiopia, Ghana, Malawi, Mali, Mozambique, Tanzania, Uganda and Zambia

Note 2. The following research institutions are merged: Kenya Agricultural Research Institute; Kenya Marine and Fisheries Research Institute; Kenya Trypanosomiasis Research Institute; Kenya Forestry Research Institute; Agricultural Science Advisory Council; Coffee Research Foundation; Tea Research Foundation of Kenya; and, Kenya Sugar Research Foundation. 
Note 3. KEPHIS is the state agency responsible for seed sector regulatory activities- plant breeders' rights registration; seed quality control; and, variety release regulation.

\section{Copyrights}

Copyright for this article is retained by the author(s), with first publication rights granted to the journal.

This is an open-access article distributed under the terms and conditions of the Creative Commons Attribution license (http://creativecommons.org/licenses/by/3.0/). 